\title{
Inhibin Beta E Chain
}

National Cancer Institute

\section{Source}

National Cancer Institute. Inhibin Beta E Chain. NCI Thesaurus. Code C129848.

Inhibin beta $\mathrm{E}$ chain (350 aa, $39 \mathrm{kDa}$ ) is encoded by the human INHBE gene. This protein plays a role in the secretion of hormones. 